\title{
Objaw Raynauda - nie zawsze choroba reumatologiczna
}

\section{Raynaud syndrom - not always a rheumatic disease}

\section{STRESZCZENIE}

Objaw Raynauda to zaburzenie naczynioruchowe o charakterze napadowym, charakteryzujące się fazowością, o etiologii pierwotnej bądź wtórnej.

Nie jest patognomoniczny dla rozpoznania chorób o podłożu autoimmunologicznym, lecz może im towarzyszyć, często wymaga analizy interdyscyplinarnej.
W każdym przypadku wskazana jest wnikliwa ocena objawów występujących u pacjenta powiązana ze szczegółową anamnezą umożliwiająca postawienie prawidłowego rozpoznania.

Forum Reumatol. 2018, tom 4, nr 4: 243-247

Słowa kluczowe: objaw Raynauda; pierwotny; wtórny; choroba Devica; przeciwciała przeciw akwaporynie 4

\section{WSTEPP}

Objaw Raynauda to zaburzenie naczynioruchowe występujące najczęściej pod wpływem bodźców fizykochemicznych lub na tle emocjonalnym, obserwowany u około 3 do nawet $15 \%$ populacji ogólnej, również u osób zdrowych, z najwyższym odsetkiem wśród kobiet.

Może mieć charakter pierwotny, mówi się wówczas o chorobie Raynauda (ok. 80\% przypadków) lub też wtórny, określany mianem zespołu Raynauda.

Pierwotny objaw Raynauda dotyczy najczęściej kobiet w młodym wieku (poniżej 40. roku życia), przebiega łagodnie i nie doprowadza zazwyczaj do powstania owrzodzeń i zmian martwiczych tkanek, choroba ma tendencję do samoistnego ustępowania.

Za rozpoznaniem wtórnego objawu Raynauda przemawiają: wystąpienie objawów po 30. roku życia, asymetria zmian, znaczne nasilenie napadów, uszkodzenie tkanek w wyniku niedokrwienia (owrzodzenia, blizny lub martwica paliczków dystalnych).
Nie jest objawem patognomonicznym, mimo to często utożsamiany jest ze współistnieniem chorób reumatologicznych.

Należy jednak pamiętać, że towarzyszy także innymi jednostkom chorobowym, a zatem jest to problem interdyscyplinarny - tak jak w przypadku przedstawionym w niniejszym artykule (tab. 1).

\section{OPIS PRZYPADKU}

Do Ośrodka autorek artykułu przyjęto pacjentkę w wieku 33 lat - z zawodu sprzedawca, obciążona niedoczynnością tarczycy, dotychczas nie była hospitalizowana, po raz pierwszy skierowano ją do Pomorskiego Centrum Reumatologicznego w celu diagnostyki w kierunku układowej choroby tkanki łącznej z powodu utrzymującego się od roku objawu Raynauda.

Przy przyjęciu zgłaszała parestezje w obrębie rąk, przedramion, kończyn dolnych, osłabienie siły mięśniowej kończyn górnych ograniczające codzienne aktywności, na przykład
Adres do korespondencji:

Anna Bazela-Zadura Pomorskie Centrum Reumatologiczne Tel.: 692389093 e-mail: a.bazela@gazeta.pl 
Tabela 1. Różnicowanie pierwotnego i wtórnego objawu Raynauda

\begin{tabular}{|l|l|l|}
\hline & $\begin{array}{l}\text { Pierwotny objaw Raynauda } \\
\text { (choroba Raynauda) }\end{array}$ & $\begin{array}{l}\text { Wtórny objaw Raynauda } \\
\text { (zespół Raynauda) }\end{array}$ \\
\hline Częstość występowania & Często (3-15\% populacji) & Rzadko \\
\hline Płeć & Częściej kobiety & Kobiety i mężczyźni \\
\hline Początek & Wczesny, zwykle przed 40 rż. & W każdym wieku, często po 30 rż. \\
\hline Symetria napadów & Symetryczne & Symetrycznie lub asymetrycznie \\
\hline Przebieg choroby & Zwykle łagodny & $\begin{array}{l}\text { Różnorodny, często intensywne } \\
\text { napady }\end{array}$ \\
\hline Owrzodzenia i martwica & Nie występują & Możliwe \\
\hline Tendencja do ustępowania objawów & Często & Rzadko \\
\hline $\begin{array}{l}\text { Wspótistnienie choroby układowej lub choroby } \\
\text { tętnic }\end{array}$ & Nie & Tak \\
\hline Przeciwciała przeciwjądrowe & Brak & Mogą być obecne \\
\hline Mikroangiopatia w badaniu kapilaroskopowym & Nie & Może być obecna \\
\hline Rokowanie & Dobre & Zależy od choroby podstawowej \\
\hline Objaw Raynauda w rodzinie & Tak & Tak \\
\hline
\end{tabular}

Źródło: Kowal-Bielecka 0., Bielecki M. Choroba i zespół Raynauda. W: Puszczewicza M (red.). Wielka Interna — Reumatologia, Medical Tribune, Warszawa 2011: 409-419

ubieranie się. Powyższe objawy pojawiły się około miesiąca przed przyjęciem na oddział, objaw Raynauda występował u chorej w charakterystycznych trzech fazach (zblednięcia, zasinienia, wtórnego przekrwienia) po ekspozycji na zimno, z nasileniem w okresach jesienno-zimowych.

Wywiad w kierunku alergii, infekcji, chorób zakaźnych, genetycznych, odkleszczowych, a także autoimmunologicznych występujących w rodzinie, niepowodzeń położniczych był negatywny.

W badaniu przedmiotowym zwracało uwagę osłabienie siły mięśniowej kończyn górnych, zasinienie skóry rąk, obrzęki palców rąk, bez towarzyszącej bolesności i obrzęków stawowych.

W wykonanych na oddziale badaniach laboratoryjnych stwierdzono nieznacznego stopnia limfopenię, podwyższony ALAT - 36 j./1 , pozostałe parametry wątrobowe utrzymywały się w zakresie norm laboratoryjnych. Celem pogłębienia diagnostyki wykonano USG jamy brzusznej, stwierdzając hepatomegalię, bez zmian ogniskowych w wątrobie i cech wolnego płynu w jamie otrzewnej. W USG rąk uwidoczniono śladowy wysięk w stawach MCP II-V, PIP II-V ręki prawej oraz MCP III-V, PIP III-V ręki lewej, bez aktywności zapalnej, obraz kapilaroskopowy uwidocznionych naczyń był prawidłowy. W panelu immunologicznym obecne były wysoko dodatnie przeciwciała przeciwjądrowe w mianie 1:5120 oraz dodatnie przeciwciała antykardiolipinowe, diagnostykę poszerzono o ANA immunoblot.
W stanie ogólnym dobrym pacjentkę wypisano do domu z zaleceniem zgłoszenia się na oddział celem ponownej weryfikacji reumatologicznej - po uzyskaniu wszystkich zleconych badań.

W ciągu kolejnych kilkunastu dni wystąpiło u chorej nagłe pogorszenie stanu neurologicznego.

W trybie pilnym, z silnymi bólami odcinka szyjnego kręgosłupa, brakiem kontroli zwieraczy, zaburzeniami chodu, osłabieniem siły kończyn górnych, przyjęto ją na oddział neurologiczny. Wówczas w badaniu fizykalnym przy przyjęciu stwierdzono: niedowład kończyn górnych szczególnie nasilony w odcinkach dystalnych, niedowład kończyn dolnych — ruch czynny ograniczony był do stóp, objaw Babińskiego lewostronnie dodatni, napięcie mięśniowe było obniżone, odruchy ścięgniste osłabione, osłabione było także czucie od poziomu Th3.

W toku procesu diagnostyczno-leczniczego zlecono badanie płynu mózgowo-rdzeniowego, konsultację okulistyczną, MRI mózgowia, nie stwierdzając istotnych odchyleń. Natomiast w MRI odcinka szyjnego kręgosłupa uwidoczniono pogrubienie rdzenia z obszarem płynowym od poziomu C2 do Th1.

Badania immunologiczne wykazały w profilu ANA immunoblot obecność przeciwciał antycentromerowych, stwierdzono także wysoko dodatnie przeciwciała przeciw akwaporynie 4, czyli kompleksowi białkowemu tworzącemu kanał wodny występującemu głównie 


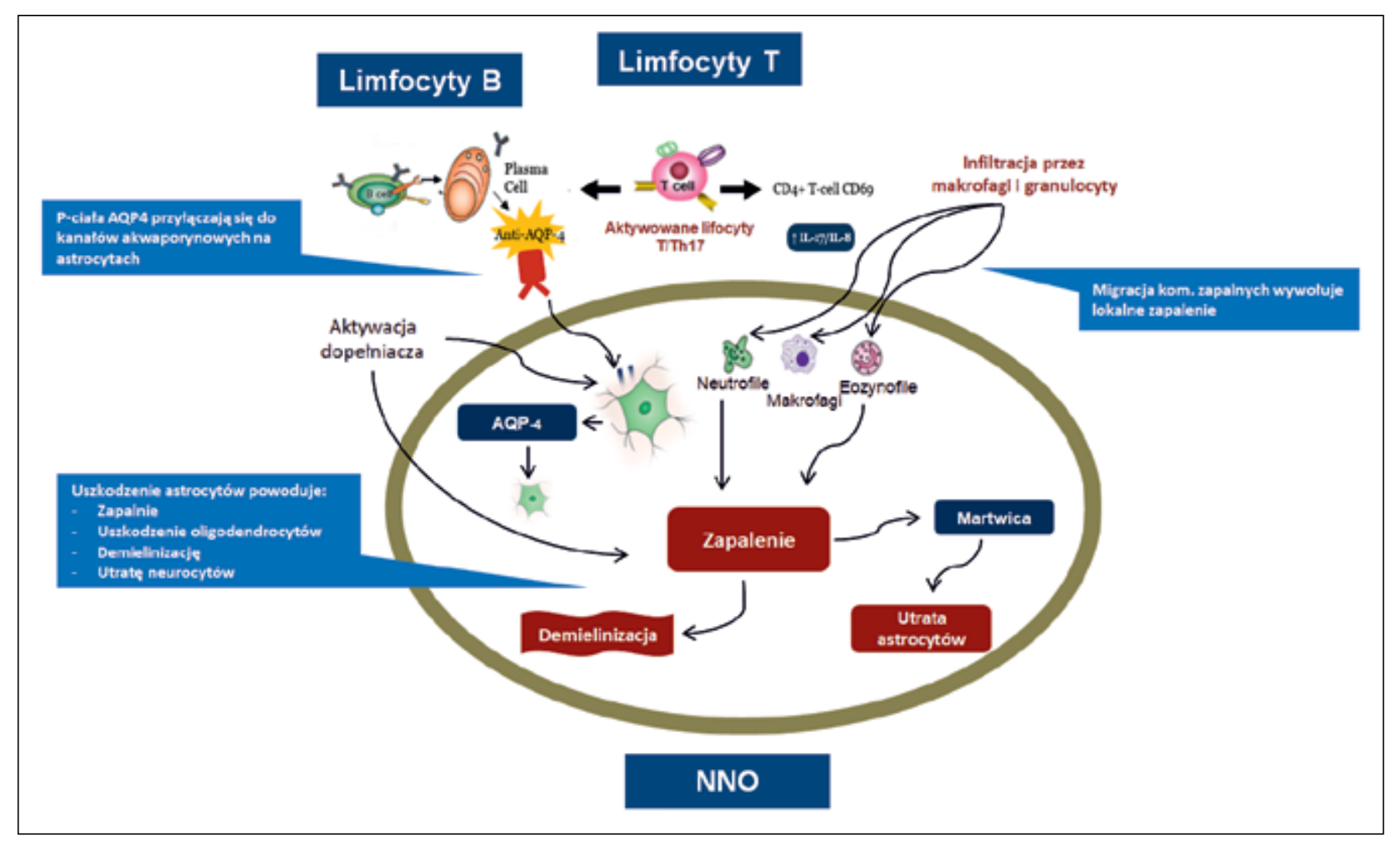

Rycina 1. Inicjacja procesu autoimmunologicznego przez przeciwciała przeciwakwaporynowe (anty-AQP-4) Żródło: 2017 Opexa Therapeutics, Inc.

na wypustkach astrocytów, ale znajdującemu się także na komórkach wyściółki i śródbłonka w ośrodkowym układzie nerwowym.

Obecność powyższych przeciwciał klasy IgG przeciw akwaporynie 4 wywołuje kaskadę zapalną i powoduje w efekcie uszkodzenie astrocytów, demielinizację z towarzyszącą martwicą i rozrostem komórek gleju (ryc. 1).

Całość obrazu klinicznego, czyli objawy neurologiczne występujące u pacjentki korelujące ze zmianami radiologicznymi oraz dodatnie przeciwciała przeciw akwaporynowe umożliwiły rozpoznanie zespołu Devica - czyli zapalenia rdzenia i nerwów wzrokowych (NMO, neuromyelitis optica).

Zespół Devica to autoimmunologiczna choroba ośrodkowego układu nerwowego o charakterze zapalno-demielinizacyjnym, z najwyższą zachorowalnością 0,5-4,4/100 000 notowaną w populacji Dalekiego Wschodu.

Średni wiek zachorowania to 39. rok życia, przebieg choroby w 80-90\% przypadków jest nawrotowy, ciężki, remisje nie są całkowite, po każdym rzucie pozostają objawy rezydualne stopniowo narastające prowadzące do niepełnosprawności.
Obowiązujące obecnie kryteria NMO wymagają spełnienia przynajmniej jednego podstawowego objawu klinicznego (tab. 2) oraz stwierdzenia obecności przeciwciał AQP4-IgG. Istnieje natomiast wiele chorób ze spektrum NMO, które nie spełniają klasycznych kryteriów, mogą być związane lub niezwiązane $\mathrm{z}$ obecnością przeciw przeciwakwaporynowych, do kręgu tych schorzeń należą: podłużne rozległe zapalenie rdzenia, nawrotowe izolowane zapalenie nerwu wzrokowego, obustronne zapalenie nerwów wzrokowych, oczno-rdzeniowa postać stwardnienia rozsianego, NMO w przebiegu chorób układowych, nietypowy obraz NMO z zajęciem ośrodkowego układu nerwowego (klinicznym lub subklinicznym).

Kryteria diagnostyczne NMO i chorób ze spektrum NMO przedstawiono w tabeli 2.

Objawy występujące u chorego z zespołem Devica często mogą naśladować inne jednostki chorobowe, na przykład stwardnienie rozsiane. Należy wówczas przeprowadzić wnikliwą diagnostykę różnicową, opierając się na wynikach wykonanych badań obrazowych (MRI mózgowia i rdzenia kręgowego z kontrastem), immunologicznych oraz ocenie płynu mózgowo-rdzeniowego. 
Tabela 2. Kryteria diagnostyczne zapalenia nerwów wzrokowych (NMO) i rdzenia oraz choroby ze spektrum NMO (NMOSD, neuromyelitis optica spectrum disorders)

\begin{tabular}{|c|c|c|c|}
\hline NMOSD AQP4 IgG (+) & NMOSD AQP4 IgG (-) & Podstawowe objawy kliniczne & Kryteria MRI wymagane dla postaci NMO IgG(-) \\
\hline $\begin{array}{l}\text { Co najmniej jeden } \\
\text { podstawowy objaw } \\
\text { kliniczny } \\
\text { Dodatnie miano } \\
\text { przeciwciał NMO-IgG } \\
\text { Wykluczenie innych } \\
\text { jednostek chorobowych } \\
\text { przebiegających } \\
\text { z podobnymi objawami } \\
\text { klinicznymi }\end{array}$ & $\begin{array}{l}\text { Co najmniej } 2 \text { podstawowe objawy } \\
\text { kliniczne (a-f), } \geq 1 \text { rzut spełniający } \\
\text { następujące kryteria: } \\
\text { Co najmniej } 1 \text { z 3: } \\
\text { 1) zapalenie nerwu II (ON) } \\
\text { 2) zapalenie rdzenia (LETM) } \\
\text { 3) objawy z area postrema } \\
\text { Rozsianie w przestrzeni, co } \\
\text { najmniej } 2 \text { gtówne objawy kliniczne } \\
\text { Potwierdzenie w badaniu MRI } \\
\text { Negatywny wynik oznaczenia } \\
\text { przeciwciał NMO-IgG lub brak } \\
\text { możliwości oznaczenia } \\
\text { Wykluczenie innych jednostek } \\
\text { chorobowych przebiegających } \\
\text { z podobnymi objawami klinicznymi }\end{array}$ & $\begin{array}{l}\text { Objawy uszkodzenia mózgu } \\
\text { z typowymi zmianami dla } \\
\text { NMOSD w MRI mózgowia } \\
\text { Objawy zajęcia area postrema } \\
\text { (czkawka, nudności, wymioty) } \\
\text { Ostre objawy pniowe } \\
\text { Objawowa narkolepsja lub } \\
\text { ostre objawy podwzgórzowe } \\
\text { z typowymi dla NMOSD } \\
\text { zmianami w MRI w podwzgórzu } \\
\text { Ostre poprzeczne zapalenie } \\
\text { rdzenia } \\
\text { Zapalenie nerwu wzrokowego }\end{array}$ & $\begin{array}{l}\text { ON: wymagany (a) prawidłowy obraz MRI mózgu } \\
\text { lub niespecyficzne zmiany w istocie białej lub (b) } \\
\text { hiperintensywne w T2 zmiany w obrębie nerwów } \\
\text { wzrokowych lub w T1 ulegające wzmocnieniu } \\
\text { kontrastowemu, obejmujące co najmniej długość nerwu } \\
\text { wzrokowego lub skrzyżowanie nerwów wzrokowych } \\
\text { Ostre zapalenie rdzenia: wymagane zmiany } \\
\text { wewnątrzrdzeniowe zajmujące } \geq 3 \text { segmenty rdzenia } \\
\text { (LETM) lub } \geq 3 \text { sąsiadujące segmenty z ogniskową atrofią } \\
\text { rdzenia u pacjentów po przebytym zapaleniu rdzenia } \\
\text { Objawy z area postrema: wymagane zmiany na powierzchni } \\
\text { grzbietowej rdzenia (area postrema) } \\
\text { Ostre objawy pniowe: wymagane odpowiadające objawom } \\
\text { zmiany w pniu mózgu }\end{array}$ \\
\hline
\end{tabular}

Żródło: Gospodarczyk-Szot K., Nojszewska M., Podlecka-Piętowska A. i wsp. Zapalenie nerwów wzrokowych i rdzenia Devica (NMO) oraz choroby ze spektrum NMO. Polski Przegląd Neurologiczny 2016; 12(4): 196-205.

AQP4 (aquaporin 4) — akwaporyna 4; IgG — immunoglobulina G; ON (optic neuritis) — zapalenie nerwu; LETM (Iongitudinally extensive transverse myelitis) — podłużne rozlegte zapalenie rdzenia

\section{DIAGNOSTYKA}

Obraz rdzenia kręgowego w zespole Devica charakteryzuje się obecnością hiperintensywnych ognisk w obrazach T2-zależnych, które ulegają wzmocnieniu po kontraście i obejmują co najmniej 3 segmenty rdzenia, z towarzyszącym obrzękiem, zmianami martwiczymi i zanikowymi.

W MRI mózgowia wyżej wymienione zmiany obecne są w około $60 \%$ przypadków. Badanie ogólne płynu mózgowo-rdzeniowego u chorych z zespołem Devica wykazuje pleocytozę monocytarną lub limfocytarną, w 46-75\% podwyższone stężenie białka, rzadziej występują prążki oligoklonalne. Celem oceny zajęcia nerwów wzrokowych wykonuje się badanie wzrokowych potencjałów wywołanych (WPW), nieprawidłowości w tym badaniu wykazuje nawet do $80 \%$ chorych.

Bardzo ważnym elementem diagnostyki jest oznaczenie przeciwciał przeciwko akwaporynie 4, które pozwalają różnicować chorobę Devica $\mathrm{z}$ innymi chorobami o podobnym obrazie klinicznym. Punktem przełomowym było ich wykrycie w 2004 roku, należy pamiętać, że niewykrycie przeciwciał AQP4 nie wyklucza rozpoznania chorób ze spektrum NMO.

\section{OBRAZ KLINICZNY}

Objawy kliniczne stwierdzane u pacjenta z zespołem Devica odpowiadają obszarowi mózgowia i rdzenia kręgowego objętemu przez proces chorobowy jak poniżej:
- poprzeczne zapalenie rdzenia wywołuje spastyczny niedowład kończyn dolnych lub niedowład czterokończynowy, zaburzenia funkcji zwieraczy, bóle korzeniowe, napadowe skurcze toniczne, objaw Lhermitte'a, oraz uporczywy świąd;

- zajęcie pnia mózgu powoduje czkawkę, nudności, zawroty głowy, neuralgię nerwu trójdzielnego, porażnienie nerwu twarzowego, niedosłuch;

— zajęcie podwzgórza może doprowadzić do zaburzeń hormonalnych — niedoczynności tarczycy, narkolepsji, zaburzeń miesiączkowania, moczówki prostej, mlekotoku, zaburzeń termoregulacji;

- zapalenie nerwu wzrokowego może występować obu- lub jednostronnie, powodując ból, ubytki w polu widzenia, błyski, w badaniu dna oka — zanik nerwu wzrokowego.

Ból jest częstym objawem towarzyszącym chorobie Devica, występuje u około $80 \%$ chorych, najczęściej lokalizując się w obrębie tułowia i kończyn dolnych. Na skutek remielinizacji uszkodzonych włókien ruchowych dochodzi po powstania bolesnych skurczów tonicznych, występują one u około $25 \%$ chorych.

\section{LECZENIE}

Standardowe leczenie pierwszego rzutu choroby Devica bądź zaostrzenia NMO to podanie metyloprednizolonu $w$ dawce $1000 \mathrm{mg} /$ dobę przez 5 dni, w razie braku poprawy stosuje się plazmaferezę. W przypadku nieskuteczności powyższej terapii lub przeciw- 
wskazań do jej stosowania zaleca się dożylne wlewy immunoglobulin (IVIg).

Leczenie pierwszego rzutu kontynuuje się najczęściej przez 2-6 miesięcy (prednizolon w początkowej dawce $1 \mathrm{mg} / \mathrm{kg}$ mc. stopniowo redukowanej) w celu obniżenia ryzyka wczesnego nawrotu objawów neurologicznych.

Przewlekłego leczenia immunosupresyjnego (azatiopryna, mykofenolan mofetilu, rytuksymab) wymagają pacjenci $\mathrm{z}$ wysokim ryzykiem nawrotu, czyli z dodatnimi przeciwciałami przeciwko AQP4 oraz spełniający kryteria rozpoznania NMO. Azatioprynę stosuje się w początkowej dawce 2,5-3,0 mg/kg mc./ dobę, stopniowo zwiększanej aż do uzyskania efektu terapeutycznego, znacząco wydłuża ona okres remisji choroby, a także pozwala na redukcję dawek steroidów. Agresywniejszym lekiem i coraz częściej stosowanym jest rytuksymab - przeciwciało monoklonalne anty-CD20, które redukuje liczbę rzutów choroby o 88,2\% w stosunku do azatiopryny $72,1 \%$.

Zgodnie $\mathrm{z}$ powyższym schematem u pacjentki początkowo zastosowano pulsy metyloprednizolonu w dawce $1 \mathrm{~g}$ przez $5 \mathrm{dni}$, a następnie steroidoterapię doustną (prednizon $60 \mathrm{mg} / \mathrm{d}$.), nie uzyskując istotnej klinicznie poprawy. W związku z utrzymującym się niedowładem czterokończynowym przeprowadzono 5 cykli plazmaferezy również bez poprawy neurologicznej, w dalszym ciągu obserwowano progresję zmian radiologicznych, zadecydowano zatem o podaniu immnonoglobulin i włączeniu azatiopryny w dawce $150 \mathrm{mg} /$ dobę oraz prednizonu $60 \mathrm{mg} /$ dobę ze stopniową redukcją dawki, uzyskując częściową poprawę. W wyniku zastosowanego leczenia pojawiły się odruchy w kończynach górnych, śladowy ruch palców stóp, napięcie mięśniowe typu scyzorykowego. Pacjentkę wypisano z ogólną poprawą, z zaleceniem dalszej rehabilitacji oraz okresowej kontroli neurologicznej.

Niestety po 1,5 roku stosowania powyższej terapii wystąpił kolejny rzut choroby pod postacią pozagałkowego zapalenia nerwu wzrokowego. Chorą wówczas zakwalifikowano do terapii rituksymabem, obecnie jest po dwóch cyklach, z dobrym efektem, utrzymano także azatioprynę $(150 \mathrm{mg} / \mathrm{d}$.) oraz prednizon (30 mg/d.). Do chwili obecnej nie obserwowano kolejnych rzutów choroby.

\section{WNIOSKI}

Podsumowując, należy pamiętać, że objaw Raynauda nie jest tożsamy $\mathrm{z}$ wystąpieniem u pacjenta choroby reumatologicznej, w każdym przypadku wskazany jest szczegółowy wywiad zarówno osobniczy, jak i rodzinny, dokładne badanie przedmiotowe oraz diagnostyka różnicowa.

Mimo dominujących na chwilę obecną u pacjentki objawów neurologicznych wymaga ona dalszego nadzoru reumatologicznego i obserwacji w kierunku układowej choroby tkanki łącznej.

\section{ABSTRACT}

Raynaud syndrom is angioneurotic disorder which episodes occur in particular phases, being primary or secondary type. It is not pathognomonic to autoimmunological diseases but often coexists with them, Raynaud phenomenon demands interdisciplinary analysis.
Every case needs rigorous evaluation of symptoms and medical history of patient to make a correct diagnosis.

Forum Reumatol. 2018, tom 4, nr 4: 243-247

Key words: Raynaud syndrom, primary, secondary, Devic's disease, aquaporin 4-antibodies
1. Puszczewicz M. Wielka Interna - Reumatologia. Med. Trib. Pol., Warszawa 2010: 66-72, 409-419.

2. Jeka S, Opoka-Winiarska V. Atlas praktycznej kapilaroskopii w reumatologii. PTR, Warszawa 2017: 51-56.

3. Zimmermann-Górska I. Interna Szczeklika. Medycyna Praktyczna, Kraków 2018: 2005-2013.
4. Zimmermann-Górska I. Reumatologia Kliniczna. Wydawnictwo Lekarskie PZWL, Warszawa 2008: 897-903.

5. Gospodarczyk-Szot K, Nojszewska M, Podlecka-Piętowska A, et al. Zapalenie nerwów wzrokowych i rdzenia Devica (NMO) oraz choroby ze spektrum NMO. Polski Przegląd Neurologiczny. 2016; 12(4): 196-205. 